\title{
ハイブリッド方式のオンライン地震応答載荷実験法の 開発と若干の動的実験
}

第 1 報

$\begin{array}{lllll}\text { 正会員 } & \text { 金 多 } & & \text { 潔* } \\ \text { 正会員 } & \text { 西 } & \text { 澤 } & \text { 英 } & \text { 和** }\end{array}$

\section{I. 序}

オンライン地震応答載猗奏験の耐震工学的な位置付け 構造物が，その耐用年限の間に数回程度遭遇すると考 えられる中規模の地震や，さらには数十年に一度といら 強大な地震に対して, 架構をいかに安全かつ合理的に設 計し，十分な耐震性を保持させるかといらことは，建築 工学の重要なテーマである。今日では,このような頻度 の小さい激震に対しては，架構部材の若干の塑性化を許 容し，履歷によるエネルギー吸収によって応答を緩和 し，部材の䩚性を高めて，耐震性を賦与するといら終局 強度の理念に基づく設計規範が一般化しつつあるが，終 局時に扝ける部材の非線型応答性状や，破壊に至る部材 の劣化機構, さらにはエネルギー吸収に伴ら部材の損傷 蓄積等の諸問題は，必ずしも充分に解明されていないの が実情である。

この主たる原因としては1)，地震によって破壊された 構造物の応答記録が皆無に近いこと，実験技術的には， 降伏点を越えた大変形領域での振動実験が極めて困難で あること, また, 数值解析の面からは, 強震時の非線型 領域に打る動特性の解析が困難で, 未だ確固たる検証 のなされていないことなどが指摘できる。

例えば, 構造物の履歷復元力特性を考慮した数值解析 的な研究法としては, 履歴特性を速度比例型の粘性抵抗 に置換し zero-memory 系として応答解析を行う方法 や, 復元力特性を数式表示し, 応答の時間的な変化を, step by step の数值積分によって追跡する方法などが一 般的であるが，第 1 番目の手法は，比較的非線型性の小 さい中小規模の地震の応答解析に適するため, 大変形時 の応答解析には，第 2 番目の方法が主流を占めている。

しかしながらこのような研究法で問題となるのは, 架構や部材の復元力特性として, bi-linear, tri-linear あ るいは, Ramberg-Osgood 等の現象論的な近似関数を 用いざるを得ないにもかかわらず，実際の架構部材の履

* 京都大学 教授・工博

***京都大学 助手・工修 (昭和 57 年 4 月 23 日原稿受理日, 討論期限昭和 58 年 4 月末日)
歴曲線の形状は，これらの数值モデルで完全に表現する ことが困難な場合も少くないことである。すなわちここ に，履歴法則や破壊規範などの材料条件を，現象論的な 数值モデルに依存する, 数值シミュレーション法の基本 的な問題点が指摘されており, 本法のみによって, 架構 の終局挙動を充分に評価するには, 方法論としての制約 が大きいと考えられている。

一方，実験的な立場からは， RC, $\mathrm{S}$ 造の加力試験に代 表されるように, 地震時の建物の信頼性を種々の供試体 の破壞実験によって 評価するという手法が一般的であ る。しかしながら，通常は 単に地震力に 相当する外力 を，準静的に載倚するに過ぎず，加力方式も，漸増載 荷, 定変位繰し載荷など, 比較的単純な場合に限られて いるのが実情である。従ってこのような方法では，部材 の最大耐力や変形能力などの強度的な知見は得られるも のの, 地震と架構の応答といら動的な相互作用までを再 現評価することができないという久点を有している。

それ故, 今後の耐震工学の研究上の重要な課題の 1 つ は，数值解析的なアプローチと実験的なアプローチの 2 つの方法論のもつ制約をいかに克服するかと言うことに あると考えられるが，このような立場から見た場合，部 材の復元力特性に関して，数值的なモデル化を要しない 振動解析法一 “オンライン地震灾答載荷実験法” は, 上 記のような課題に対する極めて有効な方法論となり得る 点で重要であると思われる。

II. オンライン地震応答載荷実験に関する基礎的考察 1969 年, 東京工業大学の伯野博士らのグループは油圧 サーボ試験機を用いて, 鋼片の復元力を求め, これをオ ンラインでフィードバックさせて，振動方程式の計算を 行うという，耐震工学上注目すべき実験を 報告してい $\Xi^{2), 3)}$ 。

この方法は, 構造物の復元力特性をあたかもアナログ コンピュータの非線型要素のごとくみなし，試験体の載 倚システム自体を演算制御系に組み入れるという，極め て巧妙な試験方法であった。この方式によると振動台に よる実験と同様，復元力特性に関する数值的な仮定を必 
要としないため，振動系の動特性をあるがままに評洒し らる可能性を有するばかりではなく, 油圧試験機の強大 なパワーとも相まって, 振動台では再現し得ないような 架構部材の破壞挙動をも, シミュレートし得ると考元ら れる点で注目された。

その後, これと同様のシステムをデジタルコンピュー 夕に置き換え, 大型の油圧装置を駆動させるようにした 本格的なオイライン実験が，1974 年頃から, 東京大学生 產技術研究所のグループを中心に展開されておりり年,5), さらに最近では，建設省建築研究所にそれを上回る。超 大型の実験システムが完成し6),7)，この種のアプローチ に対する内外の関心が高まりつつある。しかし，現時点 で報告されているシステムは，この他数例を数えるに過 ぎず8，99，14，15)，16)，普遍的な実験方法として充分に定着 するには至っていないのが奏情である。けれども元来, オンライン地震态答載荷実験法の基本原理は, 極めて単 純明快なむのであって，大規模な計測・制御システムを 用いなくとも，簡単に実現しらる構造実験技術であるこ とに注意しなければならないだろう。今日では,ミニコ ンピュータやマイクロコンピュータを用いた, デジタル 指向のシステムのほか, アナコンや微分解析機を用いた アナログ方式, 両者を併用したハイブリッド方式, さら には，アナコンの論理をデジタル的に実現するDDA 方

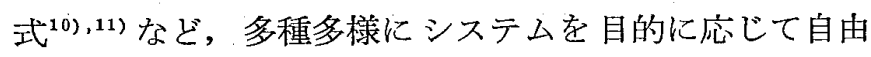
に構成することができる。

これ等を技術的に裹付けるものは，アナログ，デジタ ルの両分野に扔ける電子回路技術の飛躍的な進歩にほか ならないが，油圧装置の制御面から見た場合，OP アン プの高性能 IC 化と，マイクロプロセッサーの普及とい う2点に注目しなければならないと思われる。

前者は, 1976 年以後, いわゆる “第 2 世代の OP アン プ”の普及によって，特にその傾向が強まったが，アナ ログコンピュータを始めとする低周波回路でのドリフト 等の諸問題は実用上ほとんど解決されたと考えられる点 で ${ }^{22)}$ また後者は，超小型ながら完全なコンピュータア 一キテクチャを有して打り，さらにその hardware 及び software のいずれもが公開されているため，研究面で のコンピュータ利用を著しく容易にした点で重要であ る。

本研究は，以上の諸点を踏玉えて，“マイクロコンピ ニータ”と “第 2 世代の OP アンプ技術” の 2 つに着目 した。独自のオンライン地震応答載荷実験法について論 ずるもので ${ }^{13)}$ ，本報で示した基本的な教光方は，後のマ イクロコンピュータを利用したデジタル型のシステムの base ともなっている。

\section{1 オンライイン地震応答載渮実験の基礎式}

本報で提案するオンライン地震応答載荷実験法は，非 線型の振動方程式の解を，伯野博士等と同稼，アナログ

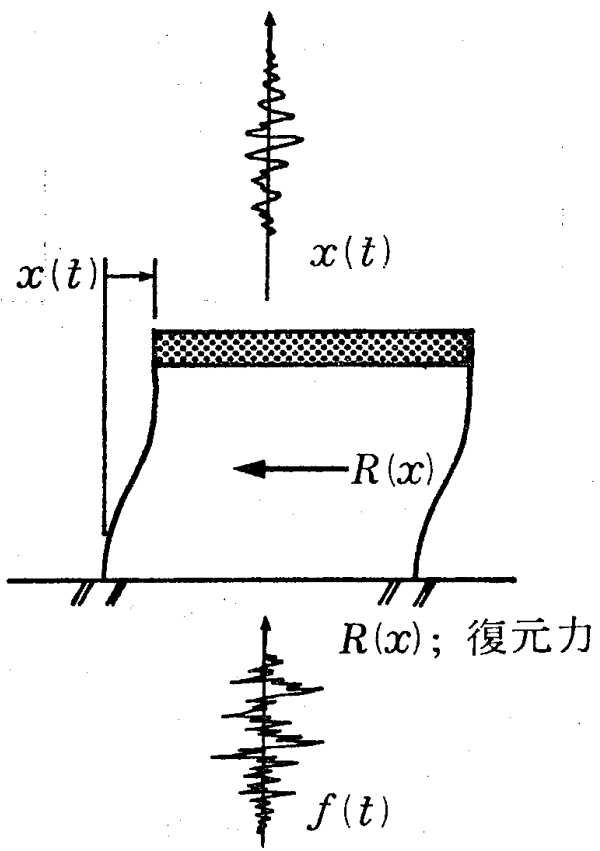

图一1 1 自由度振動系のモデル

コンピュータで直接積分して求める方式を採用している が, 演算をマイクロコンピュータのプログラムタイマー で制御する点が異なっている。な拉各パラメータは以下 の式によって決定される。

\section{アナログコンピュータの回路定数の決定}

図一1 に示すような一自由度系フレームの非線型振動 方程式は周知のように次式で表現される。

$$
\ddot{x}(t)+2 h \omega_{n} \dot{x}(t)+\frac{R[x(t)]}{m}=-F(t)
$$

ここに $\omega_{n}$ : 弾性時のフレームの固有円振動数

$h:$ 臨界減衰

$m:$ 質量

$x(t)$ :地盤に対するフレームの相対変位

$R[(t)]:$ 変位 $x(t)$ に対応する復元力

$F(t):$ 地動加速度

ここで，(1) 式をアナログコンピュータで解くには, 以下の 2 式の変換を行わね淁ならない。

$$
\left\{\begin{array}{l}
k \cdot t=\tau \\
s \cdot x=e
\end{array}\right.
$$

ここに $k:$ タイムスケールファクタ

$t:$ 実時間スケール

$\tau:$ 演算時間スケール

$s:$ スケールファクタ

$e:$ 演算電压

(2)，(3) 式を用いて (1) 式の変換すると, machine unit の振動方程式が次式のように得られる。

$$
\begin{aligned}
\ddot{e}(\tau) & +\frac{2 h \omega_{n}}{k} \dot{e}(\tau)+\frac{s}{k^{2} m} \cdot R\left[\frac{\dot{e}(\tau)}{s}\right] \\
\quad & =-\frac{s}{k^{2}} F\left(\frac{\tau}{k}\right) \ldots \ldots \ldots \ldots \ldots \ldots \ldots \ldots \ldots \ldots \ldots \ldots \ldots \ldots \ldots \ldots
\end{aligned}
$$

一方, モデルフレームを用いたオンライン地震応答载 


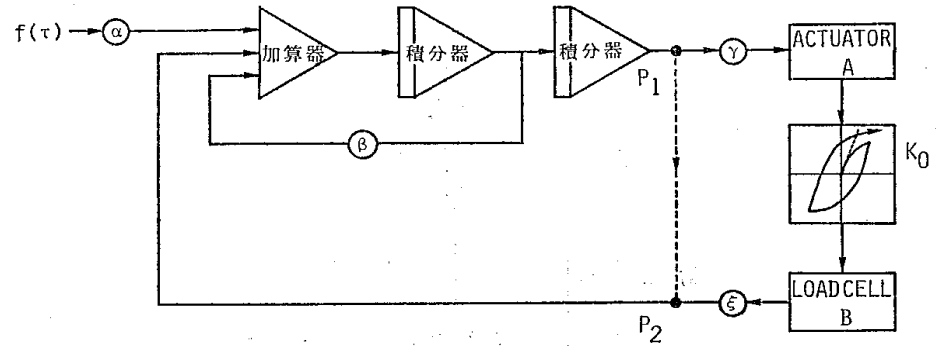

图一2 オンライン地震志答载荷実験法のブロック図 荇垁験のブロックダイヤグラムを, 図一-2のように設定 寸る。図中の記号は以下に示す通りである。

$A:$ サーボアンプの変位入力電王とアクチュエータ の機械的出力変位との比例係数

$B:$ 荷重変換器の荷重と変位出力電圧との比例係数

$K_{0}$ : 供試体の初期弾性域での剛性

$\alpha$ : 入力加速度レベルを設定するための係数

$\beta:$ 減变係数を設定するための係数

$r$ : 演算変位電压をサーボの変位に対応させるため の係数

$\xi:$ 荷重変換器からの出力電压をアナログコンピュ 一タの演算電圧に適合させるための係数

このブロックダイヤグラムから得られる回路は，次の 演算式を構成している。

$$
\begin{aligned}
\ddot{e}(\tau) & +\frac{\beta}{c} \dot{e}(\tau)+\frac{\gamma \cdot A \cdot K(e) B \cdot \xi}{c^{2}} \cdot e(\tau) \\
& =-\alpha \cdot f(\tau) \ldots \ldots \ldots \ldots \ldots \ldots \ldots \ldots \ldots \ldots \ldots \ldots \ldots \ldots \ldots \ldots
\end{aligned}
$$

ここで $\quad c:$ 積分器の時定数

$K(e)$ : 変位電圧 $e$ に対応する復元力の值

（5）式によって (4) 式を解くためには，(4)，(5) 式の 各項の係数が等しくなければならない。すなわち以下の 3 つの条件が必要である。

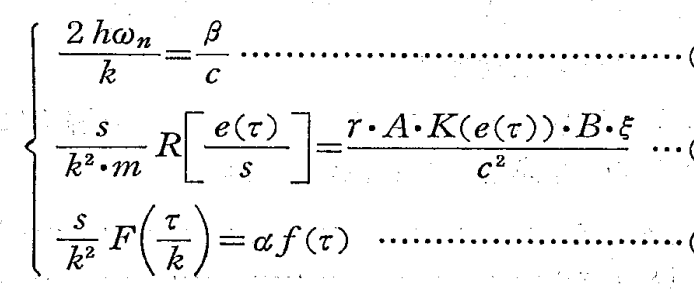

さらに,オンライン地震応答奏験においては, 単に演 算系としてだけではなく，載荷装置と供試体を含む外部 系としても, 電気的に整合していなければならないこと から，以下の 2 つの条件を考慮する必要がある。

A. 演算系として整合子るためには，実験供試体加ら 得ら扎る復元力が，(1) または（2）式で示される想定フ レームモデルの復元力の值に等しくなければならない。 特に線型弹性域であれば，(9）式が成立しなければなら ない。

$$
R\left[\frac{e(\tau)}{s}\right]_{\text {弹性恃 }}=K_{0} \cdot \frac{e(\tau)}{s}
$$

B. 弾性時の想定架構の仮定固有周期と, オンライン
地震念答載荷実験系として，載何系を経由した時の回 路によって定まる系の固有周期とが等しくなければな らない。すなわち，線型振動時には，図一2に执い て， $\mathrm{P}_{1}, \mathrm{P}_{2}$ 点を短絡した場合と，部材を継由した場合 とが，回路的に等洒であること，換言すれば， $\mathrm{P}_{1} ， \mathrm{P}_{2}$ 点の電位が等しくなければならない。式で示すと,

$$
r \cdot A \cdot K_{0} \cdot B \cdot \xi=1 \cdot
$$

従って，(9)，(10) 式老（7) 式に代入すると（12）式 が得られる。

$$
\begin{aligned}
& \frac{s}{k^{2} \cdot m} \cdot K_{0} \cdot \frac{e(\tau)}{s}=\frac{\gamma \cdot A \cdot K_{0} \cdot e(\tau) \cdot B \cdot \xi}{c^{2}} \\
& \frac{K_{0}}{k^{2} \cdot m}=\frac{1}{c^{2}} \quad \ldots \ldots \ldots \ldots \ldots \ldots \ldots \ldots \ldots \ldots \ldots \ldots \ldots \ldots \ldots \ldots \ldots
\end{aligned}
$$

(12) 式に拈いて，(13) 式を考慮すると（14）式が導か れる。

$$
\begin{aligned}
\omega_{n}^{2} & =K_{0} / m \\
k & =c \omega_{n} \cdots
\end{aligned}
$$

また，(6) 式に拟て，(14）式を考慮すると， $\beta$ は (15) 式で決定される。

$$
\beta=2 h
$$

結諭として，オンライン地震応答載荷実験を図一2の 回によって実現するためには，(14）式の条件の基で，

$$
\left\{\begin{array}{l}
r \cdot A \cdot K_{0} \cdot B \cdot \xi=1 \\
\beta=2 h \ldots \ldots \ldots \ldots . .
\end{array}\right.
$$

が成立するように， $\beta ， \gamma ， \xi$ 老決定すれば良い。な孫 数 $r$ は, 演算変位電压とサーボの出力変位の関係から試 験機の特性を考慮して定めれば良い。

\section{入力加速度の係数 $\alpha$ の決定}

ポテンショメータ $\alpha$ にる前の入力加速度電圧 $f(\tau)$ は, 最大加速度電生が $\pm V$ (volt) に対応した出力波形と なっている。すなわち地動の原加速度波形を $F(t)$ とし $\tau$

$$
f(\tau)=\frac{F(\tau / k)}{|F(\tau / k)|_{\max }} \cdot V
$$

という出力が得られている。これにはを乗しててレ心゙ルを 設定すれば良いから（8) 式より

$$
\begin{aligned}
& \frac{s}{k^{2}} F\left(\frac{\tau}{k}\right)=\alpha \cdot \frac{F(\tau / k)}{|F(\tau / k)|_{\max }} \cdot V \\
& \alpha=\frac{s \cdot|F(\tau / k)|_{\max }}{k^{2} \cdot V} \ldots \ldots \ldots \ldots \ldots \ldots . .
\end{aligned}
$$

が得られる。

実験では，最大地動加速度を（19）式で定義される降 伏加速度 $A_{y}$ を基準にその倍数 $p$ によって設定するこ とにしているので， ※は（20）式の形で与えられる。

$$
\begin{aligned}
& A_{y}=\omega_{n}{ }^{2} \cdot \delta_{y} \\
& \left(\delta_{y}\right. \text { : 想定フレームモデルの降伏変位) } \\
& \alpha=\frac{s^{2} \cdot \omega_{n}^{2} \cdot \delta_{y}}{k^{2} \cdot V} \cdot p=\frac{s^{2} \cdot \delta_{y}}{c^{2} \cdot V} \cdot p
\end{aligned}
$$

観测端子電圧の換算式

図-2 の信号観測端子電恠を $\ddot{X}, \dot{X}, X$ とすると，積 
分時定数が $c$ であることに注意すれば，

$$
\left\{\begin{array}{l}
x=\frac{c^{2}}{s} X \cdots \\
\dot{x}=-\frac{c k}{s} \dot{X} \\
\ddot{x}=\frac{k^{2}}{s} X \cdots
\end{array}\right.
$$

の以上 3 式によって元の単位へ換算することができる。

結局本システムを用いてオンライン地震柋答載荷実験 を行うに当って，変更すべきパラメータけ:

i) タイムスクールフォクタ $\left(k=c \omega_{n}\right)$

ii ) 入力加速度強度係数 $(\alpha)$

の 2 種類のみとなり，アナログ回路の定数 $\beta, \gamma, \xi$ は完 全に固定しておけば良いことが分る。このことはアナロ グコンピュータの回路を一旦設定すれば，後は入力加速 度の出力速度とゲインのみを变化させることによって， 極めて容易に広汎な棈造物のオンライン地震応答載荷実 験を行うことができることを示しており，自律制御系で あるアナログコンピュータに対して，大力なマイクロプ ロセッ少によってデジタル的に精度よく制御すれば，非 常に合理的な，ハイブリッド型演算シミュレーションシ ステムが構成し得ることになる注 1)。

\section{2 システムの基本構成}

2.2 .1 システムのブロック図

2.2 節の基䃈式に基ついて，図一3 に示すようなシス テムを開発した。本システムは，次の 3 つのニットか ら構成されるハイブリッドコンピュータである。
i) アナログロンピュータ・ュニット
ii ) マイクロプロセッサ・ユニット
iii） D/A 変掺器とイコライザー・ユニット

i）は非線型振動方程式の演算に用い，ii） は地震加速 度波形の D/A 変換器への出力制御を行う。iii) は ii) 汃 らのデジタル信号を電圧に変换し，入力レベルの調整を 行う機能を有している。各ユニットの概要は以下の通り である。

\section{2 .2 アナログコンピュータ・ユニット}

本ユニットは，1自由度のオンライン地震応答載何実 験の専用装置であるため，内分結線方式を採用している が，電気油圧式試験機に信号を出力しなければならない ので回路設計上若干の配慮を払った。すなわち，各演算 器出力段には電流ブースト回路を設けて，ドライブ能力 を強化して纱り，また，時定数については，サーボアク

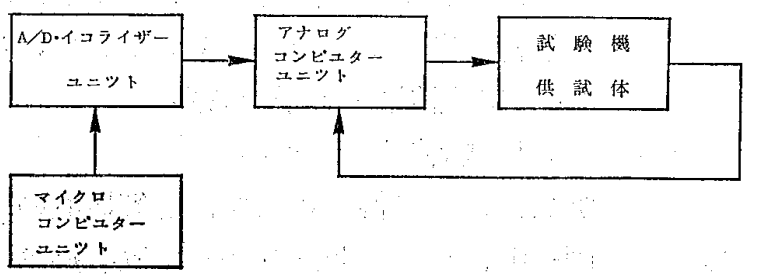

図一3 試作システムのブロック図

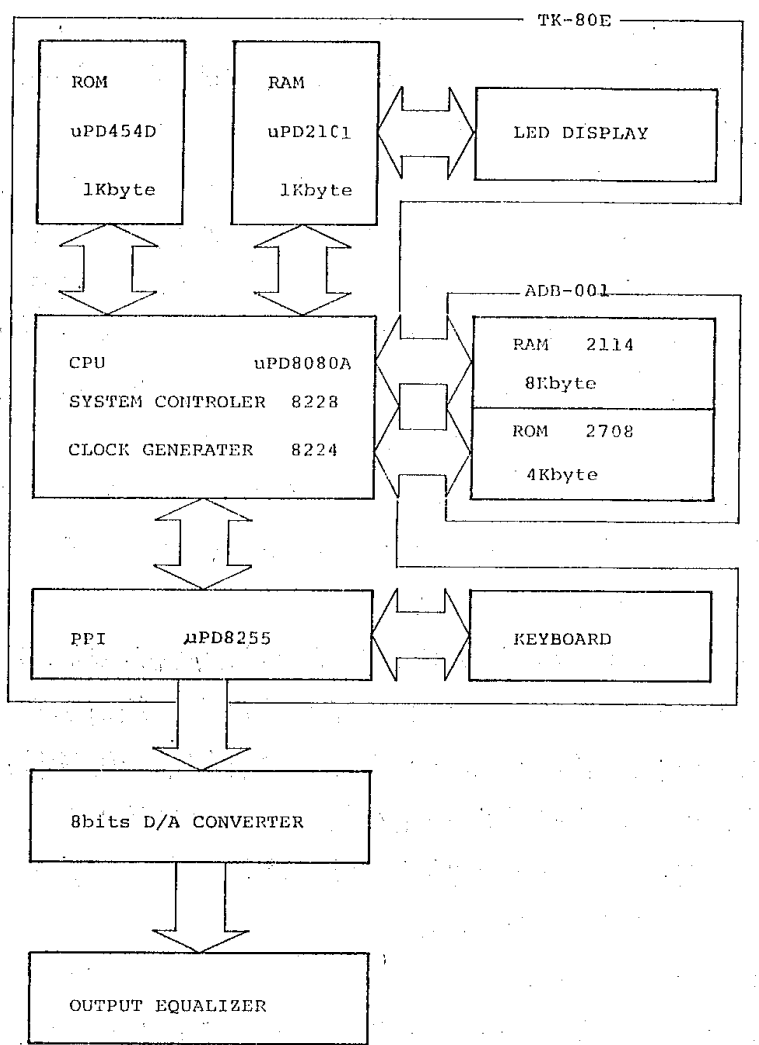

図一4地動加速度出力装置のブロック図

テュエータの周波数特性を考慮し，自励発振を生じず安 定に使用できると思われる 5 秒前後を目標に設計してい 万注 2)。

さらに，低速型アナログコンピュータで問題となる積 分コンデンサーのリーク電流に対処するため，その補償 回路を設けた結果，本ユニットのサークルテスト結果 は，0.0258\% という極めて高い值を達成している。

2.2 .3 マイクロコンピュータ・ニニット

本方式によって, 種ふの固有周期の架構モデルの実験 を行うためには，タイムスケールファクタ $k$ を正確に コントロールしなければならないので，マイクロコンピ ニータを利用した地動加速度出力装置を試作した。本装 置のブロック図は図一 4 に示寸通りであるが：基本的に ษワンボードマイクロコンピュータ (NEC・TK-80)のア ドレスデコーダを改良して，メモリーの増設をはかった むのである。イシターフェイスには，内蔵の PPI (uPD 8255）を利用した。

地震波は，1/100 秒間隔の記録波形 (20.48 秒分) を その最大值で正規化して，データの最大值が $\mathrm{FF}_{\mathrm{H}}$, 最小 值が $01_{\mathrm{H}}$ となるように，16 進デー夕に変换し，さらに 得られた加速度波形のデータは, ROM に書き込んで本 体の増設メモリーボードに塔載した。

一方データの出力制御プログラムは, 機械語でコーデ イングした後, 各命令のクロック数を計算し, プ:ログラ ム内のタイマールーチンで, 所定の出力速度が得られる よらに補正した。このプログラムも ROM に書き込ん であるため，システムは起動と同時に作動させる事が可 
能で, 最小限のデータを 16 進コードで入力することに よって，直ちにオンライン地震応答載荷実験を開始する ことができるようにエ夫した。

$$
2.2 .4 \text { D/A コンバータ・イコライザー・ユニット }
$$

このユニットは, ラッチコントロール付の 2 チャンネ ルの 8 bit D/A コンバータを有して抢り，16 進データ $01_{\mathrm{H}} \sim \mathrm{FF}_{\mathrm{H}}$ に対して, $\quad 0.00 \sim 10.00 \mathrm{~V}$ のアナログ出力 が得られるように調整している。イコライザー部は D/A コンバーターの出力電圧に $-5.00 \mathrm{~V}$ のバイアスをかけ てフォロワーを介して出力するものであるが，その際 (20) 式で計算された係数 $\alpha$ の設定を行えるよう，ポテ ンショメータを挿入している。

\section{1 層鉄骨架構のオンライン地霹応答載荷実験}

新しく開発を行ったオンライン地震応答載荷実験シス テムの性能を検討するとともに，鉄骨架構の弾塑性応答 性状に関する定性的な知見を得ることを目的として，単 純な鉄骨架構モデルの動的試験を実施したので，その概 要について以下に述べる。

\section{1 解 析架 構}

地震度系解析を行う構造物は, 図一 5 a に示すような 1 自由度系柱柱崩壊型鉄骨架構である。解析仮定は以下 に示す通りとする。

i ) はりの剛性は無限大で, 柱頭, 柱脚は完全固定 とする。

ii ）柱のせん断変形，面外変形は無視する。

iii）柱の想定軸力は，架構の固有周期と剛性から決 定するが，軸力は負荷しないものとする。徒って， $P-\Delta$ 効果や曲げ軸力相関関係は無視される。

3.2 解析架構と供試体の相似則注 4)

オンライン地震応答載荷実験に際して, 実物架構を用

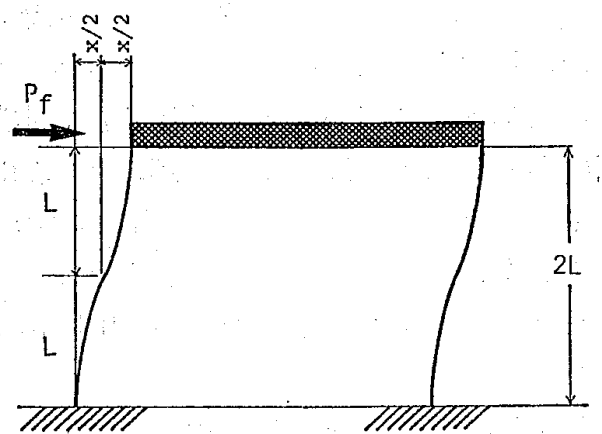

a. 解析架構の変形状態

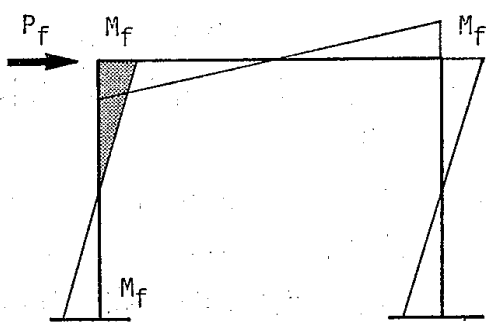

c、解析架橉の曲げモーメント図

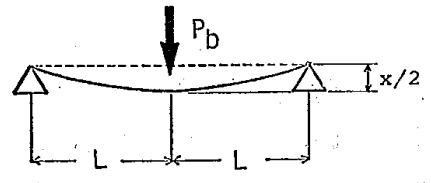

b。単純梁供試体の変形状熊

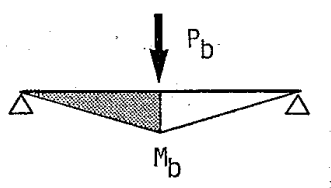

d.単純梁供武体の曲げモーメント図
図-5 解析架構と供試体の相似則
いるには制約が大きいので，架構としての特性を失わな い最小限のユニットとして, 門型架構の単純梁置換モデ ルを採用する。

図一5. c の解析フレームの復元力 $P_{f}$ と柱材端曲げモ ーメント $M_{f}$ の間には, 次式が成立する。

$$
M_{f}=\frac{P_{f} \cdot 2 L}{4}
$$

当然, この式は, 弾性, 弾塑性状態にかかわらず成立 する。

また，弾性域に新けるフレームの㴊性は，柱部材の断 面 2 次モーメントを $I$ とすると, 次式で表される。

$$
K_{f}=\frac{3 E I}{L^{3}}
$$

ここで, 解析架構と等価な復元力を得るため, 材長が $2 L$ の, 同一断面性能を有する単純梁を考㝋る（図一5. $b, d) 。$

この単純梁の弾性剛性 $K_{b}$ は, (26) 式で示され,

$$
K_{b}=\frac{6 E I}{L^{3}}
$$

また，中央に集中街重 $P_{b}$ が作用する時の中央曲げモー メント $M_{b}$ は次式のようになるから，

$$
M_{b}=\frac{P_{b} L}{2}
$$

結局, 解析架構の柱頭変位 $x(t)$ に対応寸る復元力 $P_{f}$ は単純梁の中央暁みが $x(t) / 2$ に対応する反力として得 られることが分る。こうして, 想定架棈と単純梁の弾塑 性挙動が対态付けられたので, モデル構造物の振動実験 を行わずに，その構成部材から取り出した単純梁を用い たオンライン実験によって地震応答解析を行うことがで きることになる。このような方法によれば，比較的大き 、部材を使用することができるので有利である。

\section{3 シミュレーションの概要}

単純梁試験体には, SS 41 圧延 $\mathrm{H}$ 形鋼 $(\mathrm{H}-100 \times 100 \times 6 \times 8)$ を使用し，試験体の載 荷点付近には，高炭素鋼製のスティフナを挿 入して，局部座屈を防止した。

想定架構の解析パラメータは, 固有周期と して $0.6,0.8,1.0,1.2$ 秒の 4 種類, 入力加 速度強度怯，（19）式で定義される降伏加速 度の $1.0,1.5$ 倍とし, 地震波としては $\mathrm{E} 1$ Centro 1940 (NS) を採用した。供試体の諸 元の詳細は，表一1 に示す通りである。ま た，使用試験機の性能を表一2 に示した。な 押，解析に当って $h=2 \%$ を仮定している。

3.4 実験結果と若干の考際

\section{4 .1 応答性状について}

実験によって得られた変位応答履歴の一例 在図一6 亿示す。図一6 (b) 注固有周期 0.8 秒, 入力加速度強度 $1.0 A_{y}$.のエルセントロ 
表一1（a）

\begin{tabular}{|c|c|}
\hline 使 用 部 材 & $\mathrm{H}-100 \times 100 \times 6 \times 8$ \\
\hline 龬 & $\operatorname{sS} 41$ \\
\hline 降 伏点応力 & $34.0 \mathrm{~kg} / \mathrm{mm}^{2}$ \\
\hline 降代変位 $(\sigma y)$. & $2.85 \mathrm{~cm}$ \\
\hline 初 期 剛 . 性 & 1. $59 \mathrm{t} / \mathrm{cm}^{2}$ \\
\hline 階（高（2工） & $23.0 \mathrm{~cm}$ \\
\hline
\end{tabular}

表-1 (b)

\begin{tabular}{|c|c|c|c|c|c|}
\hline 固有周期 (秒) & 想定荷重 $m(\mathrm{t})$ & 軠力比 $(\%)$ & 角速度 (Un) & $\begin{array}{c}\text { 隆伏加速度 (Ay) } \\
(\mathrm{gal})\end{array}$ & タイムフアクタ (K) \\
\hline 0.6 & 14.2 & 9.5 & 10.47 & 312 & 47.48 \\
\hline 0.8 & 25.2 & 16.9 & 7.85 & 176 & 35.60 \\
\hline 1.0 & 39.4 & 26.4 & 6.28 & 112 & 28.48 \\
\hline 1.2 & 56.7 & 38.1 & 5.24 & 78 & 23.76 \\
\hline
\end{tabular}

EL CENTRO 18.MAY 1940 NS

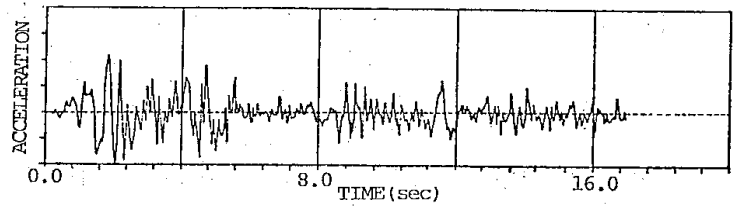

(a)

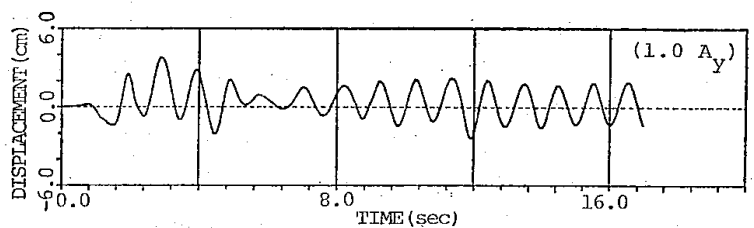

(b)

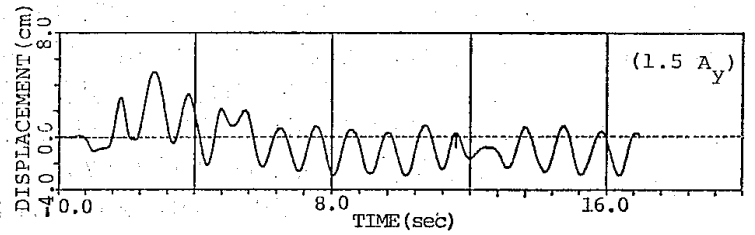

(c)

図一6 変位志答の時刻歴の一例

波の店答解析結果である。この例のように，大力加速度 強度が比較的小さい場合には，最大変位応答は入力加速 度の主要動近傍で生じ，若干の塑性化を経験するが，大 略, 架構はその固有周期で定常的な振動性状を示すこと が分る。一方，同一の構造物に対し入力加速度が $50 \%$ 程強くなった場合（図一6c) では，主要動近傍で大きな 塑性変形を生じた結果态答の中立軸の移動が顕著に認め られ, さらに, 入力地動の後期に抒いても, いわゆる plastic excursion・によって変位応答が徐々に増加する 傾向を示しており，注目に值子る。

また，架構の応答振幅は，大きな塑性変形を経験した 直後に念激に減少しており, 部材の履歴エネルギー吸収 による減衰効果の大きいことも分る。

図一6 (c) に対応する履歴曲線を図一7 に示す。履歴
表-2

\begin{tabular}{|c|c|}
\hline 最大荷重 (静的) & 17. $5 \mathrm{t}$ \\
\hline 最大荷重 (動的) & 1.5. $0 \mathrm{t}$ \\
\hline 最大ストローク & $150 \mathrm{~mm}$ \\
\hline 最大速 度 & $60 \mathrm{kin} \theta$ \\
\hline E & $135 \mathrm{~kg} / \mathrm{cm}^{2}$ \\
\hline
\end{tabular}

曲線は，変位振幅の変化や㤐答 の中立軸の移動に伴って, 複雑 な挙動をたどるが，個々のルー プは紡絓型の鋼材に特有の形状 を示している。

3.4 .2 変位灾答のフーリエ スペクトル

固有周期 0.8 秒の構造物に対 し, 入力加速度強度を, $1.0 A_{y}, 1.5 A_{y}$ に変化させた 時（エルセントロ波）のフーリエスペクトルを図-8に 示す。

この図からも明らかなよらに, 架構の応答特性は, 弾 性域を起えて，塑性化するにつれて，一般的には，低周 波域でのスペクトルの顕著な増大が認められるようにな り, またそれに付随して, 高周波の混在も認められるよ らになる。こうしたスペクトルの平準化法応答の带域が 広がって，架構が地動の不規則な波形の影響をより受け 易くなったことを示唆している。

3.4 .3 最大変位応答スペクトル

計 8 回のオンライン地震店答載荷実験によって得られ た最大変位念答を, 靸性率の形で無次元化して整理した ものが，図-9 である。図中の破線は，比較のために， 地動加速度強度が， $1.0 A_{y}$ の時の弾性時の応答スペク トルを示したものである注3)。

最大変位スペクトルは，短周期の方がその值が大き

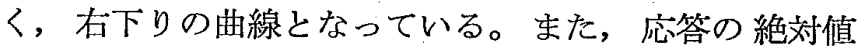
は, 入力加速度が大きい程, 大きくなるが, 固有周期に よっては, さほど加速度強度の影響を受けない場合もあ

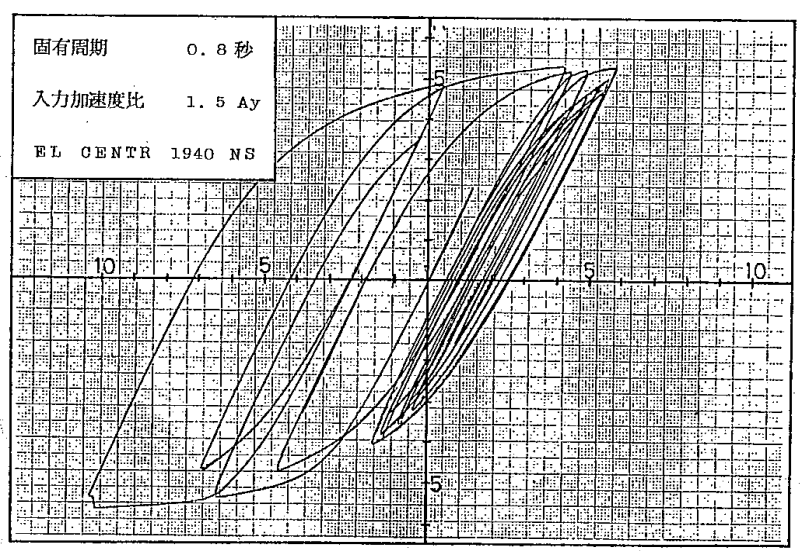

图一 7 復元力特性の一例 


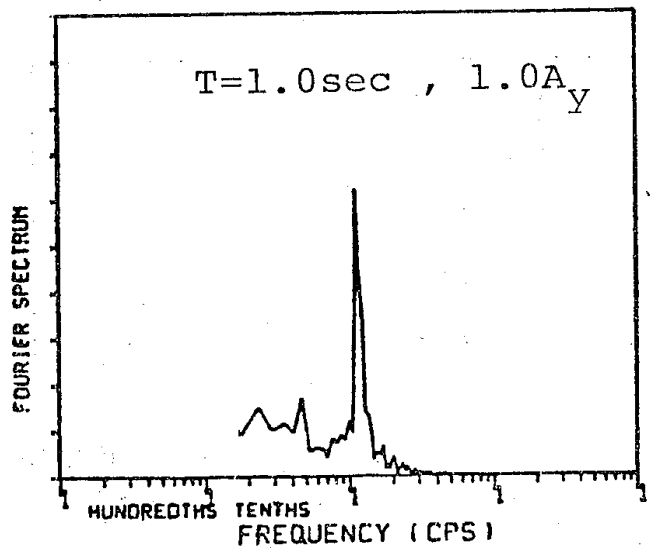

(a)

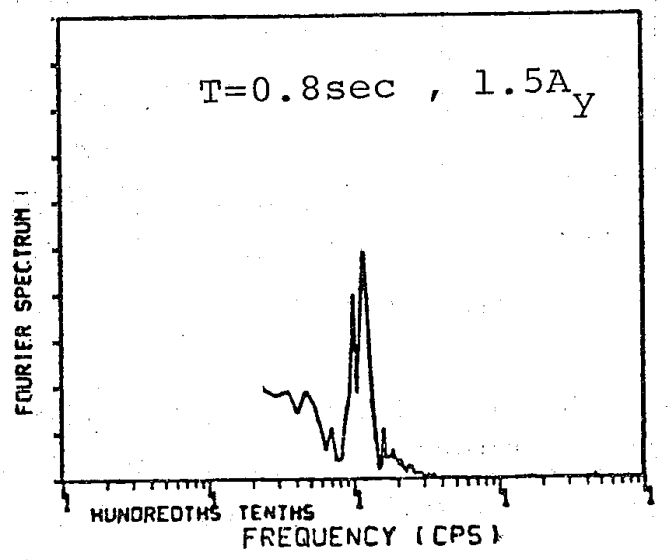

(b)

图一8 変位応答のブリエスペクトル
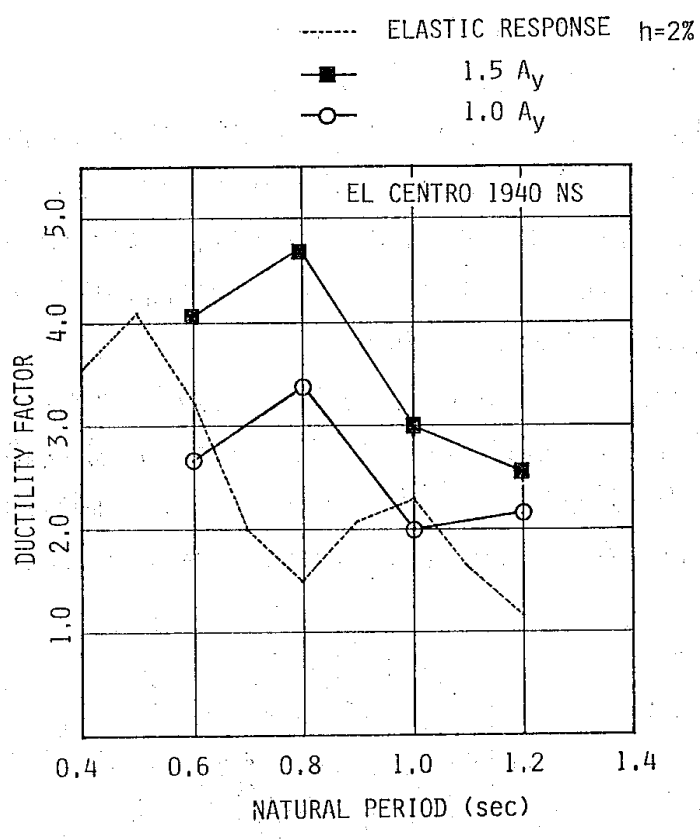

图一9 変位応答スペクトル

った。

\section{IV. 結 …語}

ハイブリッドコンピュータを利用した，オイライン地

震応答載荷実験法を提案し，之の基礎式を示すととも に，その試作システムの概要の報告を行った。さらに， このシステムを用いて，鉄骨架構の弾塑応答性状の把握
を目的として，単純な架構モデルの応答解析を実施し， 楛干の考察を行った。

この結果, 本システムは, 容易に, 単純架構のオンラ イン地震応答載荷実験を実現し得ることが碓認された。

謝

本研究を行うに当り, 試験機の使用について御便宜を 賜りました京都大学交通土木工学科, 助教授 亀田弘行 博士並びに同土木工学科, 助教授 家村浩和博士に厚く 御礼申し上げます。また，本研究のシステムの開発及び 実験に熱心に従事された三菱重工 (株)，酒井良樹氏 (当 時大学院生）に感射の意を表します。

\section{参考文献}

1） 家村浩和，P.C. Jenings : “強震記録を利用した R.C. 建 築物 の 少化履歴復元力解析”, 土木学会諭文報告集, 第 230 号, 1974 年 10 月, p. 33

2）伯野元彦，四俵正俊，原司：“計算機により制御され た，はりの動的破壞実験”，土木学会論文報告集，第 171 号, 1969 年 11 月, pp. 1 8

3）伯野元彦，横山功一，佐藤安一郎：“模型杭基礎の復元力 特性に関するオンライン・リアルタイム実験”, 土木学会 論文報告集，第 200 号，1972 年 4 月, pp. 85 90

4）例えば高梨晃一，宇田川邦明他：“電算機試験機オンライ ンシステムによる構造物の非線型地震応答解析 (その 1: システムの内容), 日本建榮学会論一文報告集, 第229 号, 昭和 50 年 3 月, pp. $77 \sim 83$

5）岡田恒男, 関 松太郎：“電算㙨ーアクチュエータオンラ インシステムによる鉄筋コンクリート骨組の地震㐫答実 歌 (その 1 )”, 日本建築学全論文報告集, 第 275 号, 昭和 54 年 1 月, pp. 25 31

6）例えば，阔本 伸，䆶田敏行他：“仮動的手法以上る寒大 構造物の地震応答実験（その 1 6)” 昭和 55 年度, 日本 建築学会学術謴演梗概集 (棈造), p. 695 706

7）窯田敏行，北川良和他：“鉄筋コンクリート造試験体によ る動的加力実験手法に関寸る研究（その 1 4)”, 昭和 56 年度日本建築学会学術講演梗概集 (構造)，pp. 879 884

8）：後藤尚男，龟田弘行，小池 武他：“地震時の鋼構造部材 の塑性疲労破填に開する確率統訢的考察”，第 4 回日本地 震工学シンポジウム講演集, pp. 855 862 (1975)

9) Y. Yamada, H. Iemura : "Hybrid Analysis on Earthquake Response of Deteriorating Hysteretic Structures" Proc. of. The Sino-American Symp. on Bridge and Structural Eng. Beijing, Sept. 1982 (to appear)

10）穗坂 衛: コンピュータグラフィックス, 座業図書, p. 93 (1964)

11）水畑耕治, 前田幸典, 田中達彦: “デジタル・ダイナミッ ク・シミュレーターによる地震応答解析”, 第 4 回電子計 算機利用シンポジウム, 1982, pp. $91 \sim 96$

12）トランジスタ技術，1978 年 6 月号，p. 153〜180

13）金多 潔, 西沢英和, 酒井良樹：“ON-LINE REAL TIME HYBRID SIMULATION SYSTEM による铁 骨建築物の蔽震性状の評洒记関する基礰的研究”, 日本建 築学会近畿支部報告集, 昭和 54 年 6 月, pp. 349 352

14）宮沢健二：“オンラインシステムによる 1 質点 Hard Spring 型構造物の非線型振動解析について”，日本建筑 学会大会学術講演梗概集 (九州), 昭和 56 年 9 月, pp. 1911 1912

15），望月利男：“くい一上部構造物連成系の，振動特性に関する オンラインリアルタイム実験 “( I )”, 日本建築学会論文 報告集, 第 231 号, 昭和 50 年 8 月

16）望月利男, 小泉敏一，北川 博, 長狛文雄 : “実験装犆一 電算機オンラインシズテムによるくい一上部 構造物連成 
系の地震応答解忻”，日本建築学:会関東支部報告集（昭和

51 年), pp. $41 \sim 44$

注 1）载荷速度と復元力の評価について

1 自由度系の 振動方程式を $m \ddot{x}+Q(\dot{x})+R(x, \dot{x})=$ $P(t)$ とすると，本システムで実版的に得られる復元 力は, 綮密には上式の 2,3 項和 $Q(\dot{x})+R(x, \dot{x})$ で 与えられる広義の復元力に相当する。そのため載渮速 度が大きい場合には，本文 (1) 式で踟界娍衰比 $h$ を 陽に与えているので, 速度減衰の評価を 2 重に考慮す る可能性も指摘される。

しかしながら，本システムの定常振動時の載荷速度 は, 後述の様に周期 $T \doteqdot 30$ (秒)注 2) となるように設 定しているため，応答最大振幅 $A \div 5(\mathrm{~cm})$ とした場 合でも, 載荷系の最大速度は高々 $2 \pi A / T \div 1.0$ (kine) 程度である。従って本載荷システムは，既往のオンラ インシステムより若干載荷速度は大きいものの，あく まで，準静的実験の一種と見なすべきであり，その意 味では, 観測復元力に対する速度減衰の寄与以僅かで あると判断される。このことは，低速型の電気油圧試 験機を用いた本地震応答載荷実験システムでは, 振動 台のように動的な復元力特性を評仙することができな いことを意味するものであり，本システムの技術的制
約の一つと言える。

注 2) 本アナログコンピュータの実測時定数は，4.535 秒で めった。従って図一2 のシステムは, 弾性振動時に は, 28.494 秒の固有周期を有する。

注 3）通常の忍答スペクトルは, 地震加速度の強度を一定と した時の各種固有周期の架構の最大応答をプロットし たものであるが，ここでは，入力の降伏加速度比を一 定とした時の最大変位を示している。従って入力加速 度強度は，表一1 に示すように，固有周期によって異 っている。

な拉，比較のために示した弾性時のスペクトルは本 システムによる実験值ではなく，数值計算で得られた 值である。

注 4) ここで用いられている解析架構の考え方は 既に文献 (4),(5)，(6) 等でも採用されているが，本システムは 振動台の上うに; 加速度波形を直接，構造物の基盤に 入力するのではなく, 架棈の応答変位を棈造物のもデ ル部材に加えることが基本となるので, 通常の構造実 験々同様, 試験体の加力系の境界条件を適切に設定し て，架構部材の応力状態に近くなるようにしなければ ならず，加力方式によって相似則は異ってくる。

\section{S Y N O P I S}

UDC : 624.042.7:620.1:681.3:624.014.2

\section{FUNDAMENTAL STUDY ON EVALUATION OF SEISMIC BEHAVIOR OF STEEL STRUCTURES BY ON-LINE HYBRID SIMULATION SYSTEM}

by Dr. KTYOSHI KANETA, Prof. of Kyoto Univ., and HIDEKAZU NISHIZAWA, Assistant of Kyoto Univ., Members of A.I.J.

The author's group has developed a method of analysis to find nonlinear earthquake response of structures by using an on-line real-time hybrid simulation system composed of an analogue computer, an 8-bit microprocessor, and full-scale steel structural members. Details of the system and the computing method of an equation of motion are described herein.

Since the restoring forces of a non-linear structure are actually too complicated to assume the proper mathematical model, it is much more reasonable that the real responses of the structure are computed by using the actual restoring forces than making any assumption of hysteretic force deflecton relations. Therefore, in this system, the restoring forces obtained from the experiment of a real structural member were substituted into the term of the equation of motion.

Based on this approach, the non-linear seismic behaviors of single degree-of freedom structural frame subjected to strong motion earthquakes were experimentally simulated by the foregoing system. And were investigated the relations between the non-linear responses and the natural period of the structures, or the intensity of the input accelerations. 